\title{
ASSESSING GROUND AND SURFACE WATER SCARCITY INDICES USING GROUND AND SURFACE WATER FOOTPRINTS IN THE TEHRAN PROVINCE OF IRAN
}

\author{
ReZAEI KALVANI, S. ${ }^{1}-$ SharaAi, A. ${ }^{1 *}-$ MANAF, L. $^{1}-$ HAMIDIAN, A. ${ }^{2}$ \\ ${ }^{1}$ Faculty of Environmental Studies, Universiti Putra Malaysia, \\ 43400 UPM Serdang, Selangor, Malaysia \\ ${ }^{2}$ Department of Environmental Science and Engineering, Faculty of Natural Resources, \\ University of Tehran, Karaj, Iran \\ *Corresponding author \\ e-mail: amirsharaai@upm.edu.my; phone: + 60-3-8946-8031; fax: +60-3-8946-7468
}

(Received $1^{\text {st }}$ Dec 2018; accepted $12^{\text {th }}$ Feb 2019)

\begin{abstract}
Water consumption is increasing at an alarming rate all over the world. Iran is currently facing high water stress as a consequence of mismanagement. The aim of this study is to evaluate the agricultural ground and surface water footprints in the Tehran province of Iran in order to establish agricultural ground and surface water scarcity indices. Blue and green water footprints were evaluated based on the water footprint method. The volume at which ground and surface water is generated was obtained via fieldwork and GIS (Geographic Information System) data for the first time. In addition, an indicator for evaluating the agricultural ground and surface water scarcity index was established. The total groundwater footprint for the production of crops in Tehran was half of the total water footprint in 20142015. The results showed very high agricultural groundwater stress and moderate surface water stress. Groundwater abstraction for the agricultural sector was more unsustainable than surface water. Besides, agricultural ground and surface water scarcity indices are more suitable than existing indicators because they disclose environmental impact of crops production and help stakeholders to assess groundwater and surface water management policies. The agricultural water footprint should be reduced to sustain agricultural water consumption in Tehran.
\end{abstract}

Keywords: agricultural water footprint, water management, CROPWAT model, GIS data, water scarcity

\section{Introduction}

Freshwater as an essential resource for humans and the ecosystem should be considered a mandatory requirement for sustainable development (Chenoweth, 2008). Agriculture is the sector with the highest water consumption in the world (Rijsberman, 2006). The use of freshwater resources for agricultural activity contributes to the reduction in water availability for other users (Rijsberman, 2004). Iran is facing severe water scarcity, lack of precipitation, population growth and mismanagement, as well as inefficient water use in the agricultural sector (Madani, 2014). Moreover, per capita water consumption was $7 \mathrm{~m}^{3}$ in 1956 but later decreased to $2.160 \mathrm{~m}^{3}$ in 1996 , which further dropped to $1.900 \mathrm{~m}^{3}$ in 2006 (Zehtabian et al., 2010). Agricultural activity is responsible for more than $92 \%$ of freshwater consumption (Zehtabian et al., 2010). Moreover, the number of drying lakes and rivers is increasing in Iran. For instance, the Zaiyanderoad and Oromeyeh lakes have dried in recent years (Madani, 2005; Fathian et al., 2014). Besides that, the groundwater level in Iran is dramatically declining as a consequence of decreasing rainfall and water mismanagement (Khaki et al., 2018). The rate of reduction in groundwater level in Iran from 2002 to 2012 was $-0.89 \mathrm{~cm} /$ year (Khaki et al., 2018). Groundwater in arid climates is mostly used for the irrigation of 
crops (Zektser and Everett, 2004). It is documented that groundwater is identified as a crucial natural resource in most countries due to low probability of pollution, uniform distribution, good quality, and not being affected by evaporation (Zektser and Everett, 2004). Besides that, increasing groundwater demand and inappropriate groundwater management create concerns for groundwater shortages and over-exploitation of this limited water resource (Gleeson et al., 2012). Most water management methods are interlinked with surface water and there is a lack of attention to groundwater management, resulting in an increase in water depletion (Gleeson et al., 2012). Unsustainable groundwater abstraction is evident in many regions (Umar, 2004). The agricultural sector is responsible for more than $70 \%$ of freshwater abstraction and $90 \%$ of consumptive water use in the world (Fiedler and Zhang, 2009). Thus, it is essential to know the type of water source for irrigation in order to know the anthropogenic impact on water resources (Burke, 2002). Recently, due to the rapid reduction in groundwater level, identifying the type of blue water (the volume of irrigation (Hoekstra et al., 2011)) resource is regarded as an important topic in terms of interest (Siebert et al., 2010). It is claimed that groundwater for irrigation accounts for $43 \%$ of total water consumption on the global scale (Siebert et al., 2010).

In the past decades, many studies have investigated water scarcity indicators to evaluate water scarcity and contribute water management methods. The Falkenmark indicator is based on water resources available per person at a national scale. It is described as a ratio of the total water availability for human needs. A water scarcity index (WSI) lower than 500 shows that the area is a water scarcity area (Falkenmark and Lundqvist, 1998). In the Smakhtin water scarcity method (2004), water scarcity is modified via considering environmental water requirement in the water stress formula. WSI equals to the amount of water extraction divided by available water quantity after taking away the environmental water requirement on an annual scale (Smakhtin et al., 2004). Water scarcity is defined as a function of water availability to the population (Rijsberman, 2004). Moreover, physical water stress areas are arid areas with dense populations such as Central Asia, West Asia, and North America, with accessibility to less than $1000 \mathrm{~m}^{3}$ per capita per year (Rijsberman, 2004). Ma et al. (2015) investigated water stress as a fraction of total water footprint to water availability (Ma et al., 2015). Zeng provided a simple method to evaluate water stresses in different regions. This index is a component of quantity and quality of blue and green water (the volume of rainwater (Hoekstra et al., 2011; Zeng et al., 2013). Raskin index is based on water use per resource (WUPR), which is a suitable index for evaluating environmental impact on aquatic ecosystems (Raskin et al., 1996). Hoekstra evaluated monthly water stress at a global scale. Blue water stress is described as a fraction of blue water footprint to blue water availability after subtracting the environmental flow requirement (Hoekstra et al., 2012). Available water quantity is the amount of water in internal resources plus the amount of entering from outside resources in river basin (Liu et al., 2017). Moreover, Variability of monthly blue water scarcity evaluated at river basin scale by Zhuo et al. (2016, 2019). Green water stress equals to the amount of green water footprint divided by available green water quantity (Veettil and Mishra, 2016). Besides, in the Pfister method, a monthly water stress index is introduced, which is the ratio of water consumption to the modified water availability. This is the square root of the variation factor (Pfister and Bayer, 2014). Xinchun evaluated water stress in the agricultural sector using total water footprint. Water stress in the agricultural sector is found using 
green, blue, and grey water footprints. Water stress is defined as the ratio of total water footprint in the agricultural sector to total water availability (Xinchun et al., 2017).

On top of those methods, different dimensions of water stress indexes should be considered to provide more information about water stress. There is a lack of attention on separately evaluating blue water stress as groundwater and surface water scarcity. In this study, ground and surface water footprints are assessed separately to evaluate surface and groundwater stresses in the agricultural sector. Besides, Groundwater and surface water footprint were evaluated in the water footprint method in one category as blue water footprint, while in this study, these kinds of waters were evaluated separately as groundwater footprint and surface water footprint.

The objective of this study is to evaluate the agricultural ground and surface water footprints in the Tehran province in order to establish agricultural ground and surface water scarcity indices.

This study yields useful information for managing and achieving sustainable ground and surface water consumption. Moreover, When WF was accounted with the water scarcity index, it could produce an effective investigation result for water management and decision makers by providing them with useful knowledge (White, 2015).

\section{Materials and methods}

\section{Study area}

The Tehran province is situated in the north of the central plateau of Iran with a population of more than 12 million people (approximately $18 \%$ of the Iranian population) (Statistical Center of Iran) and situated in $35.724842^{\circ} \mathrm{N}, 51.381653^{\circ} \mathrm{E}$. The southern part of the province has a semiarid climate but the northern part experiences a mountain climate. The province covers an area of $18,909 \mathrm{~km}^{2}$. Figure 1 shows the average monthly precipitation and average monthly temperature during 2007-2015 obtained from the Mehrabad weather station (IMO, Iran Meteorological Organization). The Jajrud and Karaj rivers are the largest rivers in the Tehran province. Around $60 \%$ of water withdrawal in Tehran is abstracted from groundwater including wells, springs and qanats (Ministry of Energy in Tehran).

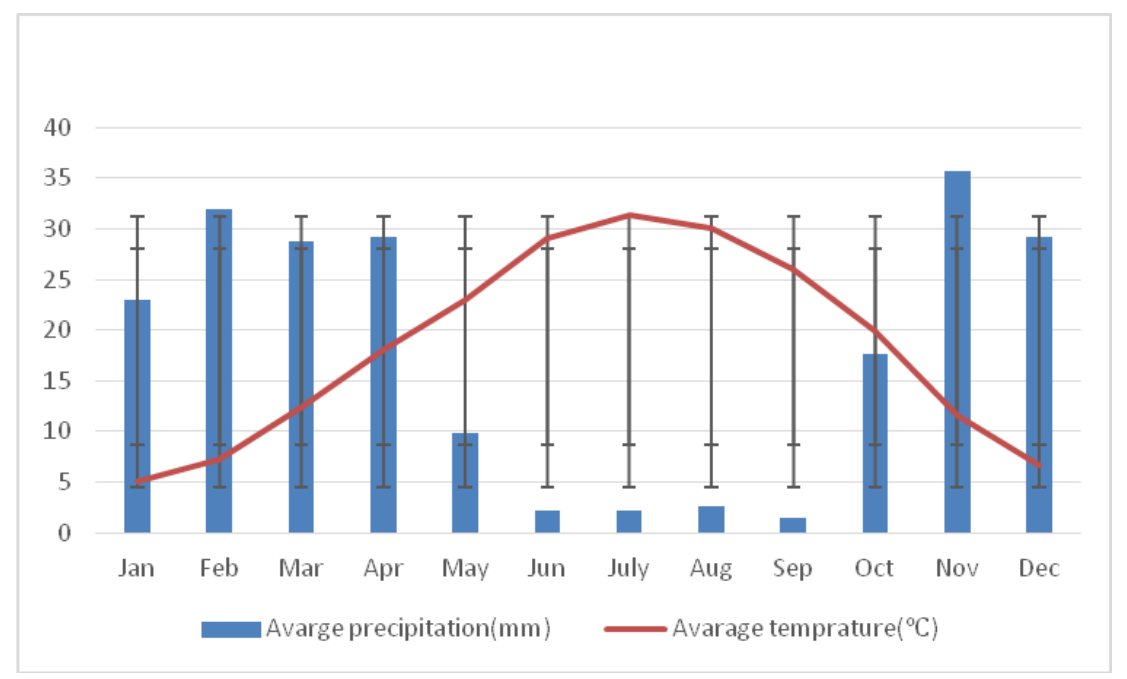

Figure 1. The plot of average temperature and average precipitation with related standard deviation (2007-2015) 


\section{Data}

Climate data were obtained from the Mehrabad Weather Station (Iran Meteorological Organization, 2018). The data for crop yield were obtained from the Ministry of Agriculture, Jahad, in Tehran (IMAJ, Iran's Ministry of Agriculture Jihad, 2018). Crop parameter data (KC [crop coefficient], day of crop growth, depth of root, critical depletion, yield response, and crop height) were obtained from OPTIWAT (Optimization Water use in agriculture) software (Alizadeh and Kamali, 2009), which is local databases for Iran. The volume of production by ground and surface water were obtained using field work and GIS data (Fig. 2) (obtained from the Ministry of Energy in Tehran). The ground and surface water use and availability were obtained from the Ministry of Energy in Tehran (Fig. 3).

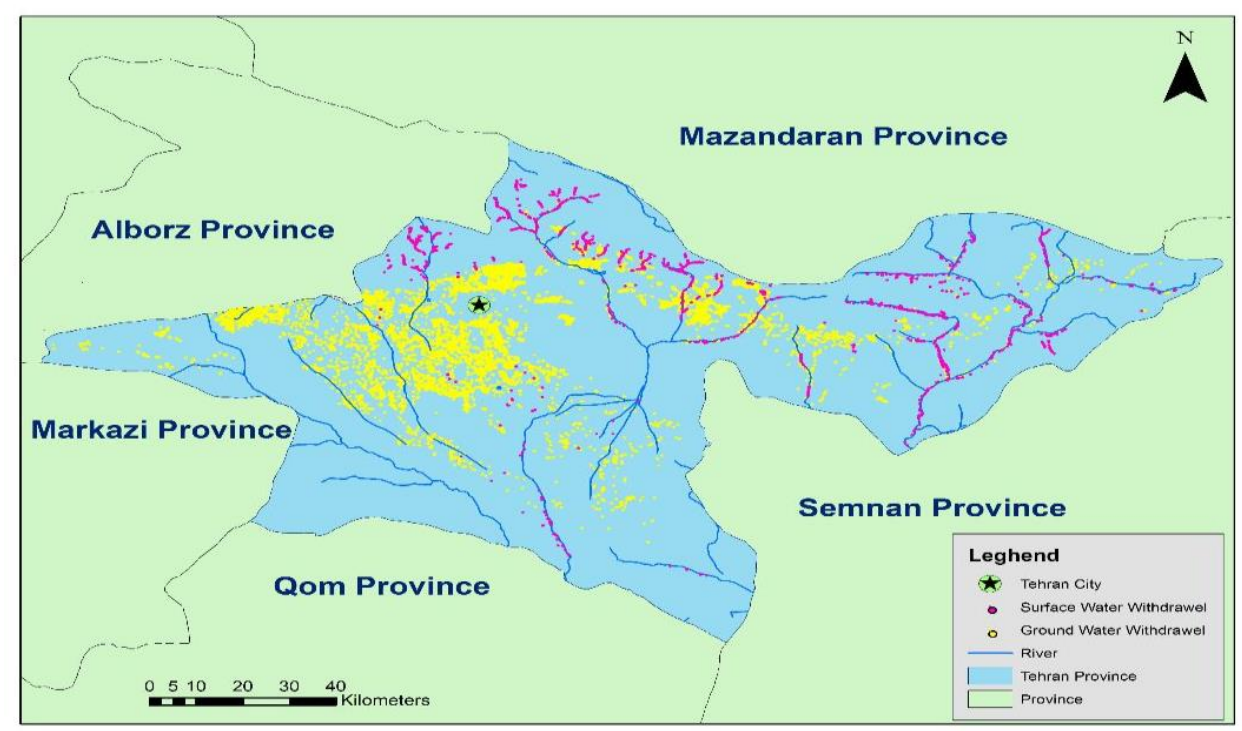

Figure 2. Surface and groundwater withdrawal for agricultural sector in Tehran province

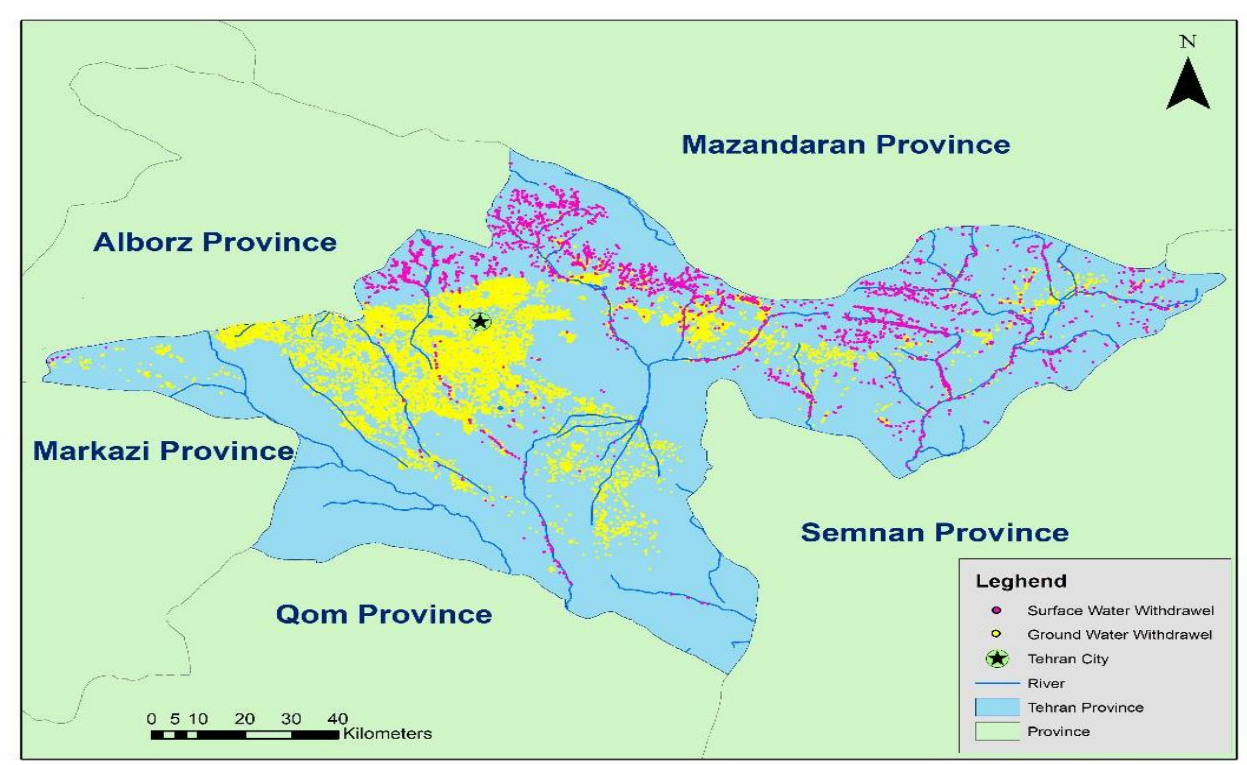

Figure 3. Total surface and groundwater withdrawal of Tehran province 
The primary crops cultivated in Tehran are apple, apricot, cherry, sour cherry, pear, plum, almond, walnut, pistachio, pomegranate, peach, wheat, alfalfa, barley, bean, cotton, maize, tomato, potato, grapes, melon, watermelon, and onion. In this study, the water footprint of these crops was evaluated from 2007 to 2015.

\section{Evaluation of agricultural ground and surface water stress indices}

The agricultural ground and surface water stress indices (AWSI ground and AWSI surface) were evaluated separately in this study (Fig. 4). The agricultural water stress index is the fraction of water used (WW) to water availability (WA), as per Equation 1 (Xinchun et al., 2017).

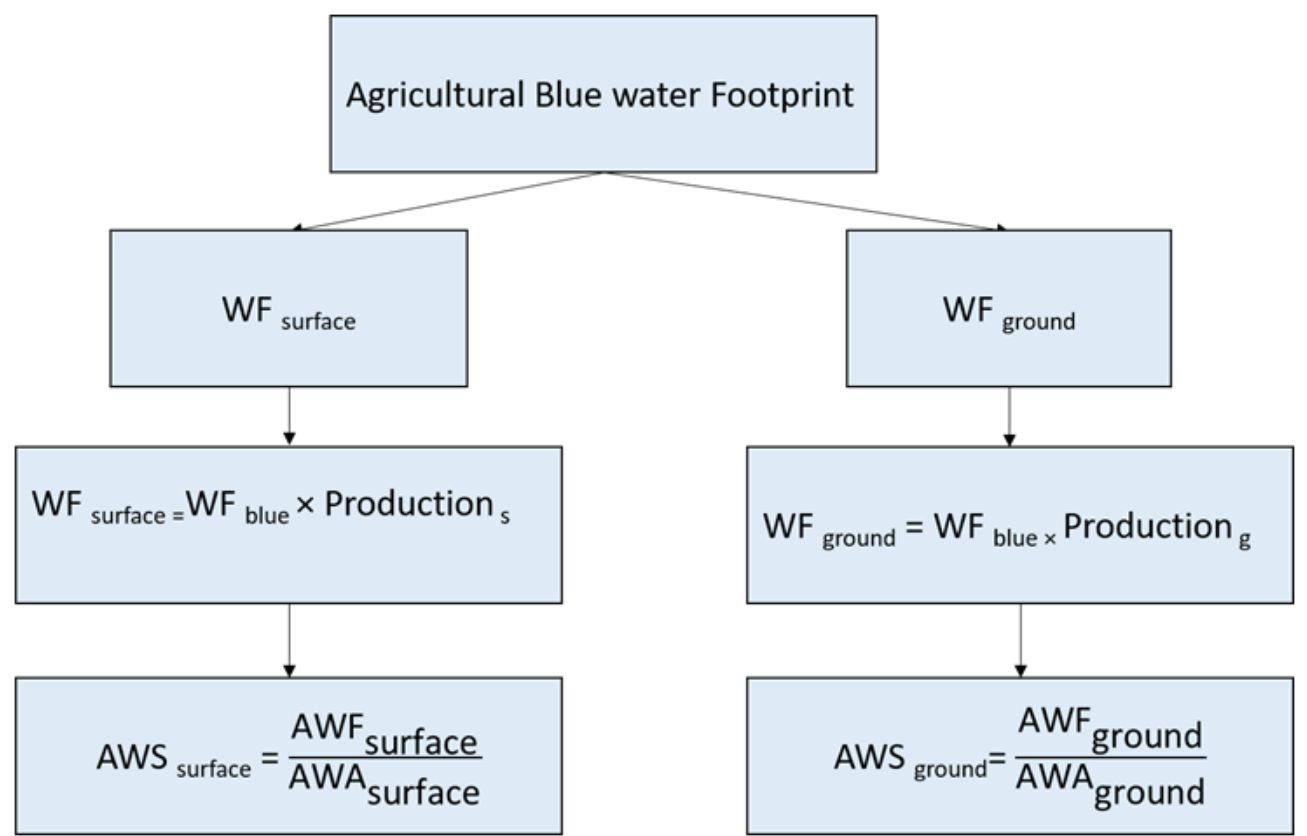

Figure 4. The accounting framework for computing the ground and surface water stress in agricultural sector. $W F_{\text {surface }}=$ surface water footprint, $W F_{\text {ground }}=$ groundwater footprint, Production $_{g}=$ the volume of production by groundwater, Production ${ }_{s}=$ the volume of production by surface water, $A W S_{\text {surface }}=$ Agricultural Surface Water stress, $A W S_{\text {ground }}=$ Agricultural Groundwater stress, $A W A_{\text {surface }}=$ Agricultural Surface Water Availability, $A W A_{\text {ground }}=$ Agricultural Groundwater Availability

$$
W S I=\frac{W W}{W A}
$$

In this study, AWSI was evaluated as the agricultural groundwater stress index (AWS ground) and agricultural surface water stress index (AWS surface). AWS surface is the fraction of surface water footprint $\left(\mathrm{m}^{3} /\right.$ year) to the agricultural surface water availability ( $\mathrm{m}^{3} /$ year), as per Equation 2. Similar consideration can be done for the evaluation of agricultural groundwater stress AWS ground.

$$
A W S_{\text {surface }}=\frac{A W F_{\text {surface }}}{A W A_{\text {surface }}}
$$




$$
A W S_{\text {ground }}=\frac{A W F_{\text {ground }}}{A W A_{\text {ground }}}
$$

Water scarcity is ranked as presented in Table 1.

Table 1. Baseline score for assessment of water stress index

\begin{tabular}{c|c}
\hline AWSI $<0.1$ & Low water stress \\
\hline $0.1<$ AWSI $<0.5$ & Moderate \\
\hline $0.5<$ AWSI $<0.9$ & Severe water stress \\
\hline AWSI $>0.9$ & Extreme water stress \\
\hline
\end{tabular}

\section{Evaluation of agricultural blue and green water footprints}

The methodology used for the evaluation of water footprint was based on a method by Hoekstra The blue and green water footprints of crop production in the Tehran province was assessed for years 2014 to 2015. The CROPWAT software was used to evaluate crop water requirement and irrigation based on soil, climate and crop data (Allen et al., 1998).

The blue water and green water footprints of different crops were evaluated using Equations 4 and 5 (Hoekstra et al., 2011).

$$
\begin{gathered}
W F_{\text {blue }}=\frac{C W U_{\text {blue }}}{\text { Yeild }} \\
W F_{\text {green }}=\frac{C W U_{\text {green }}}{\text { Yeild }}
\end{gathered}
$$

where, WF blue and CWU blue are the blue water footprint and crop water use $\left(\mathrm{m}^{3} / \mathrm{ha}\right)$, respectively, yield (ton/ha) (Hoekstra et al., no date). The reference crop evapotranspiration $\left(\mathrm{ET}_{0}\right)$ was evaluated based on the Penman-Monteith equation (Allen et al., 1998)

Crop water use was evaluated by multiplying 10 with ET (evapotranspiration) (Hoekstra et al., 2011; Eqs. 6 and 7).

$$
\begin{gathered}
C W U_{\text {green }}=10 \sum_{d}^{\lg p} E T_{\text {green }} \\
C W U_{\text {blue }}=10 \sum_{d}^{\lg p} E T_{\text {blue }}
\end{gathered}
$$

where, ET blue and ET green were the evapotranspiration of blue water and green water, respectively. The assessment was based on growing time from planting to the harvesting period as a whole. To convert water depth in $\mathrm{mm}$ into water per surface area $\left(\mathrm{m}^{3} / \mathrm{ha}\right)$ a factor 10 was applied (Hoekstra et al., 2011). The calculation of Evapotranspiration was started from the time of planing $(\mathrm{d}=1)$ and continued until the harvesting time (lgp is the days of growing crops) (Hoekstra et al., 2011). 
ET blue and ET green were accounted for using the CROPWAT software (Allen et al., 1998). An assumption was taken with climate data and the crop parameter. Climate data included maximum temperature, sum of precipitation, wind speed, humidity, sunshine, and crop parameter. ETblue was accounted for by subtracting effective rainfall (eff rain) from evapotranspiration (ETc). However, ETgreen was considered as the minimum effective rainfall and evapotranspiration, given by Equations 8 and 9, respectively (Hoekstra et al., 2011).

$$
\begin{gathered}
E T_{\text {blue }}=E f f_{\text {rain }}-E T c \\
E T_{\text {green }}=\operatorname{Minimum}\left(E f f_{\text {rain }} \& E T c\right)
\end{gathered}
$$

\section{Evaluation of groundwater and surface water footprint}

Groundwater footprint was calculated by multiplying the blue water footprint $\left(\mathrm{m}^{3} /\right.$ ton) and the volume of production by groundwater $\mathrm{P}_{\text {ground }}$ (ton/year), as per Equation 10. The same method was used to evaluate the surface water footprint, as per Equation 11.

$$
\begin{aligned}
& W F_{\text {ground }}=W F_{\text {blue }} \times \mathrm{P}_{\text {ground }} \\
& W F_{\text {sufface }}=W F_{\text {blue }} \times \mathrm{P}_{\text {surface }}
\end{aligned}
$$

\section{Evaluation of production by ground and surface water}

The volume of production by ground and surface water was obtained via fieldwork and GIS data (obtained from the Ministry of Energy in Tehran) (Fig. 2). First, the volume of crop production in each region was accounted for. Then, GIS data were contributed to know the type of water used (groundwater and surface water) for the agricultural sector and volume of water used. Fieldwork contributed to discovering the volume of production by groundwater and surface water exactly.

\section{Results}

Table 2 shows the yield, the volume of production by ground and surface water, ground and surface water footprint, and cultivated area in the Tehran province. The production of wheat consumed was $158,973,775.35 \mathrm{~m}^{3} /$ year of groundwater and $58,626,083.65 \mathrm{~m}^{3}$ of surface water. Alfalfa consumed $92,250,581.5 \mathrm{~m}^{3}$ groundwater and $75,477,748.5 \mathrm{~m}^{3}$ of surface water. The result illustrates that wheat has the largest groundwater footprint. Alfalfa has the second largest groundwater footprint, followed by barley. Besides that, the groundwater footprint for the production of all crops was bigger than surface water footprint unlike pistachio, which had a somewhat larger surface water footprint (Table 2). Besides that, the largest groundwater was related to cereal (wheat, barley, and maize) production because cereal is produced in a large scale. After cereal production, apple consumed the largest groundwater footprint because it is produced on a large scale. Pistachio and cotton with large virtual water $\left(\mathrm{m}^{3} /\right.$ year) have low groundwater and surface water footprint because the production is at a low scale. 
Table 2. Crop production (ton), yield ( $\mathrm{kg} / \mathrm{ha}$ ), groundwater footprint, surface water footprints, and cultivated area (ha) for all the cultivated crops in Tehran (2014-2015)

\begin{tabular}{c|c|c|c|c|c|c}
\hline Name of crops & $\begin{array}{c}\text { Production by } \\
\text { groundwater } \\
\text { (ton) }\end{array}$ & $\begin{array}{c}\text { Production by } \\
\text { surface water } \\
\text { (ton) }\end{array}$ & $\begin{array}{c}\text { Yield } \\
(\mathbf{k g} / \mathbf{h a})\end{array}$ & $\begin{array}{c}\mathbf{W F}_{\text {ground }} \\
\left(\mathbf{m}^{\mathbf{3}} / \mathbf{y e a r}\right)\end{array}$ & $\begin{array}{c}\mathbf{W F} \text { surface } \\
\left(\mathbf{m}^{\mathbf{3}} / \mathbf{y e a r}\right)\end{array}$ & $\begin{array}{c}\text { Cultivated } \\
\text { area (ha) }\end{array}$ \\
\hline Wheat & 128,101 & 68,977 & 4,836 & 15897375.3 & 58626083.6 & 40750 \\
Alfalfa & 119,805 & 89,023 & 16,528 & 92250581.5 & 75477748.5 & 13179 \\
Barley & $98,583.5$ & $50,583.46$ & 4,137 & 66839640 & 34432541 & 36104 \\
Bean & 457 & 236 & 2,492 & 216855 & 291885 & 9 \\
Cotton & 2,704 & 2,814 & 1,810 & 53466 & 104842 & 11 \\
Maize & 916,495 & 515,529 & 50,177 & 56822690 & 31962798 & 28539 \\
Tomato & 74,880 & 40,320 & 47,242 & 8835840 & 4757760 & 2439 \\
Potato & 33,085 & 19,431 & 28,213 & 4830410 & 2836926 & 1861 \\
Grapes & 51,323 & 24,152 & 12,500 & 42341475 & 19925400 & 6188 \\
Melon & 10,291 & 11,149 & 47,120 & 679206 & 735834 & 455 \\
Water melon & 14,874 & 7,663 & 52,048 & 892440 & 459720 & 433 \\
Onion & 23,167 & 10,108 & 50,374 & 857179 & 385096 & 667 \\
Apple & 271,893 & 90,631 & 33,500 & 55466172 & 18488520 & 11101 \\
Apricot & 29,632 & 13,313 & 15,000 & 15764224 & 7082516 & 3329 \\
Cherry & 62,737 & 20,912 & 13,400 & 29047231 & 9682256 & 6385.5 \\
Sour cherry & 5,580 & 2,170 & 10,000 & 3465180 & 1347570 & 805 \\
Pear & 15,375 & 6,590 & 17,000 & 9209625 & 3946811 & 1395 \\
Plum & 11,816 & 5,064 & 15,630 & 5340832 & 2288928 & 1099 \\
Almond & 266 & 98 & 2,326 & 933660 & 343980 & 156.5 \\
Walnut & 2,226 & 954 & 2,100 & 10767162 & 4614498 & 1641 \\
Pistachio & 1,649 & 1,463 & 1,200 & 10397625 & 13057275 & 4350 \\
Pomegranate & 8,883 & 3,454 & 12,499 & 5827248 & 2265824 & 1070 \\
Peach & 17,280 & 6,720 & 24,000 & 5028480 & 1966520 & 1100 \\
\hline
\end{tabular}

Figure 5 shows that green water footprint contributes the least to the total water footprint in the Tehran province. The production of grapes contributed to the largest green water footprint in comparison with other crops. Besides that, the production of all crops consumed larger groundwater. The production of cotton consumed the lowest groundwater and surface water because it was produced in a low volume.

Groundwater footprint makes up $52 \%$ of the total water footprint. This means that the production of crops in Tehran has a groundwater footprint that is one half of the total water footprint. Meanwhile, surface and green water footprints account for $28 \%$ and $20 \%$ of total water footprint, respectively (Fig. 6). The ground and surface water footprints for the production of crops were 585 and 322 million $\mathrm{m}^{3} /$ year, respectively, accounting for $59 \%$ and $28 \%$, respectively, of total water consumption in the Tehran province (2014-2015). However, the green water footprint is the lowest contributor to the total water footprint in the Tehran province, accounting for $20 \%$ of total water footprint. 


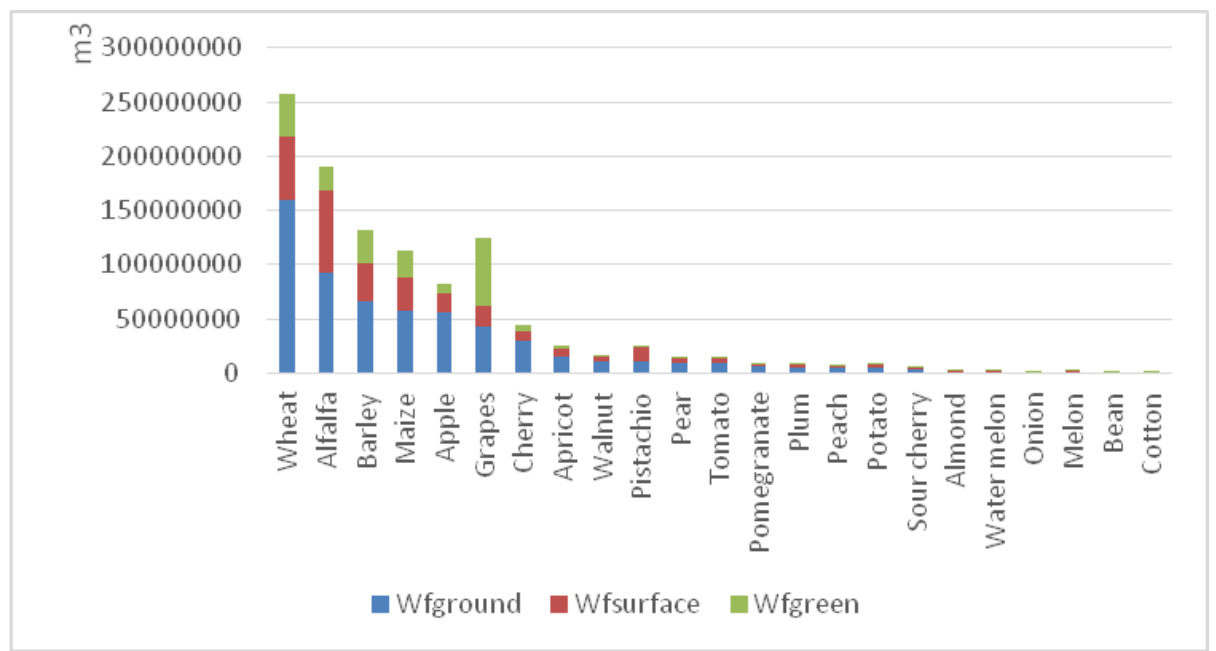

Figure 5. Ground, surface and green water footprints (cube meter/year) in Tehran province (2014-2015)

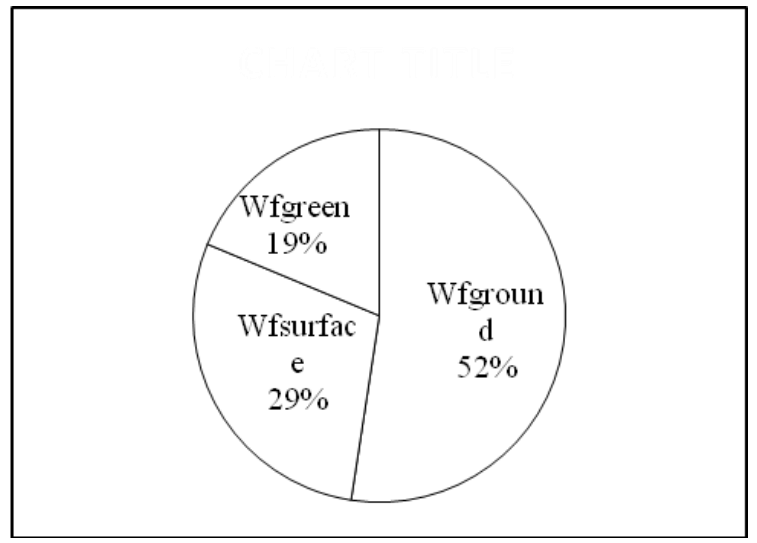

Figure 6. The proportion of surface, ground, and green water footprints in the total water footprint (2014-2015)

\section{Ground and surface water scarcity}

Ground and surface water scarcity is evaluated based on ground and surface water footprints. The result illustrates that the agricultural sector in the Tehran province is under high water stress. The production of agricultural crops relies on groundwater resources. The agricultural groundwater and surface water stresses accounted for 0.95 and 0.4 , respectively. It can be observed, therefore, that groundwater stress is very high. The Tehran province is under moderate surface water stress for the production of crops. Additionally, agricultural water consumption is unsustainable since the production of crops contributes to high groundwater stress and moderate surface water stress.

\section{Discussion}

In this study, the agricultural ground and surface water stress indices were established and determined. Besides that, this indictor divided blue water stress into groundwater and surface water stresses. These indices are different from the previous 
water stress indicator, which was based on green and blue water footprints and water availability (Xinchun et al., 2017). Besides, the Falkenmark and Raskin indexes are based on water resources available per person and water use per resource (WUPR), respectively (Falkenmark and Lundqvist, 1998; Raskin et al., 1996). Currently, most water scarcity assessments focus on blue water and total water scarcity indexes (Pfister and Bayer, 2014; Hoekstra et al., 2012; Liu et al., 2017; Zhuo et al., 2019). Other evaluations are based on total water stress (Smakhtin et al., 2004; Ma et al., 2015; Zeng et al., 2013). However, in most methods, there has been a lack of attention on the evaluation of ground and surface water scarcity. In this study, ground and surface water footprints are assessed separately to separately evaluate surface and ground water stresses in the agricultural sector.

The investigations of groundwater and surface water footprints conducted separately as a component of blue water was a difficult process since it was time consuming and laboring. This study used GIS data which contains information about the sources of water consumption (groundwater and surface) and the volume of production in each region to evaluate the surface WF and ground WF. However, in some places, there were both groundwater and surface water, and evaluation was done according to field work and using GIS data.

The green water stress was not evaluated since it did not impact blue water availability (Pfister and Bayer, 2014). However, Savenije believed that it should be accounted for because it can reduce blue water consumption (Savenije, 2000). Evaluation of water footprint at the local scale can be produced more accurately than in the country or global scale (Ababaei and Etedali, 2016).

Having knowledge of groundwater will prevent over-exploitation of limited water resources. Additionally, it also contributes to optimal priority being given to ground and surface water consumption in the agricultural sector (Tillotson et al., 2014). Determining the kind of water resource can determine illegal groundwater withdrawal.

According to this research, the agricultural groundwater consumption in Tehran province is more unsustainable than its surface water's. Besides, Tehran province is under sever groundwater stress, similar to what found by (Karandish et al., 2018). Moreover, some other studies at country scale observed that groundwater consumption in Iran is unsustainable (Gleeson et al., 2012). Besides that, groundwater depletion occurs in Iran (Mekonnen and Hoekstra, 2016). Moreover, Iran as a semiarid region is under high water stress (Wada et al., 2011)

Besides, the result indicates that crop production in Tehran has the largest ground and surface WF compared to other countries, similar to Hoekstra's result who claims that water footprint of Iran is high due to low productivity and high evapotranspiration (Hoekstra and Chapagain, 2007; Fader et al., 2011). Moreover, wheat is produced on a large scale. In other words, the production of wheat should be reduced on a large scale since the production of wheat has consumed a large ground and surface water footprint. Furthermore, arid climates have larger water usage than humid regions (Ibidhi and Ben, 2018). Besides that, since the production of all the crops is highly reliant on ground and surface water, it will be beneficial to reduce the production of these crops inside Tehran.

Decision makers should increase water saving by importing water intensive crops such as wheat since Tehran province is under severe agricultural groundwater scarcity. Virtual water trade plays an important role in mitigating water shortages in waterstressed areas (Qian et al., 2018). 
However, the production of grapes is consumed more in green water. It is recommended that the production of grapes be increased, which has lower ground and surface water footprint. Besides that, the volume of cereal production (wheat, barely, and maize) should be reduced since the production of these three crops consumed $282,636,105.5$ and 125021423.53 groundwater and surface water respectively.

\section{Conclusion}

Tehran's total water footprint (excluding grey water footprint) in the agricultural sector was 1,115,962,823.8 $\mathrm{m}^{3} /$ year (2014-2015). Groundwater footprint was $585,041,121.97 \mathrm{~m}^{3} /$ year, accounting for $52 \%$ of total water footprint. Surface water footprint was $321,943,927.03 \mathrm{~m}^{3} /$ year, accounting for $29 \%$ of total water footprint. Green water footprint was 208,977,774.8 $\mathrm{m}^{3} /$ year, accounting for $19 \%$ of total water footprint. Groundwater consumption contributed the largest share of blue water footprint in the Tehran province. Additionally, more than half of the total water consumption in Tehran was due to the groundwater footprint. Groundwater resources include wells, qanat and springs. Groundwater consumption has led to water scarcity in many parts of the province. Green water footprint contributes to the lowest share of total water footprint. The production of crops in Tehran is relatively reliant on limited groundwater resources. Therefore, the environmental impacts of blue water footprint cannot be overlooked. Thus, it is essential to establish an indicator for blue water scarcity based on ground and surface water stresses at the regional scale. This indicator reveals information about the status of ground and surface water resources at the provincial scale. Moreover, the result of this research provides beneficial information for decision makers in the water sector to help alleviate pressure on ground and surface water consumption. For instance, policy makers can prioritize water consumption to reduce water scarcity.

The productions of wheat, alfalfa, and barley have the largest groundwater footprint because these crops are produced at a large scale. Moreover, agricultural groundwater stress in the Tehran province is very high, which is 0.95 . Agricultural surface water stress was only at a moderate level, which was 0.4. Besides that, the production of agricultural crops in the Tehran province is unsustainable. Agricultural water footprint should be reduced in order to achieve sustainable agricultural water consumption in the Tehran province. It is suggested that future water stress assessments evaluate the environmental impact of ground and surface water consumption separately using the life cycle impact assessment method. Despite Tehran being under severe groundwater stress, some agricultural crops produced extra and are imported to other regions (apple and barley) (excluded from this paper) that are produced in a large scale. The decision maker should reduce the production of cereal, which consumes a large volume of groundwater and surface water footprint. Besides that, the production of apple and barley for exporting purposes should be reduced. Water management should relocate crop production in Tehran. The production of grapes can be increased while the production of cereal should be reduced. Besides that, agricultural ground and surface water scarcity indices are more suitable than existing indicators because they disclose environmental impact of crops production and help stakeholders to assess groundwater and surface water management policies. 
Acknowledgements. The authors would like to gratefully acknowledge Universiti Putra Malaysia (GP/2018/9592300) for supporting this research project.

\section{REFERENCES}

[1] Ababaei, B., Etedali, H. R. (2014): Estimation of water footprint components of Iran' s wheat production. - Environmental Processes 1: 193-205.

[2] Allen, R. G. et al. (1998): Allen_FAO1998 Crop Evaporation Guideline for Computing Crop Water Requirements. - FAO Irrigated and Drainage Paper 56, FAO, Rome, Italy.

[3] Burke, J. J. (2002): Groundwater for Irrigation: Productivity Gains and the Need to Manage Hydro-Environmental Risk. - In: Llamas, R., Custodio, E. (eds.) Intensive Use of Groundwater Challenges and Opportunities. Chapter 3. Balkema Publishers, Lisse.

[4] Chenoweth, J. (2008): E-assessment of indicators of national water scarcity. - Water Int 33: 5-18.

[5] Fader, M. et al. (2011): Internal and external green-blue agricultural water footprints of nations, and related water and land savings through trade. - Hydrol. Earth Syst. Sci. 15: 1641-1660.

[6] Falkenmark, M., Lundqvist, J. (1998): Towards water security: political determination and human adaptation crucial. - Natural Resources Forum 22: 37-51.

[7] Fathian, F., Morid, S., Kahya, E. (2014): Identification of trends in hydrological and climatic variables in Urmia Lake basin, Iran. - Appl. Climatol. 119: 443-464.

[8] Fiedler, K., Zhang, J. (2009): Global-scale analysis of river flow alterations due to water withdrawals and reservoirs. - Hydrol. Earth Syst. Sci. 13: 2413-2432.

[9] Gleeson, T. et al. (2012): Water balance of global aquifers revealed by groundwater footprint. - Nature 488: 197-200.

[10] Hoekstra, A. Y. et al. (2011): The Water Footprint Assessment Manual. Setting the Global Standard. - Earthscan, London.

[11] Hoekstra, A. Y., Chapagain, A. K. (2007): Water Footprints of Nations: Water Use by People as a Function of Their Consumption Pattern. - In: Craswell, E. et al. (eds.) Integrated Assessment of Water Resources and Global Change: A North-South Analysis. Springer, Dordrecht, pp. 35-48.

[12] Hoekstra, A. Y. et al. (2012): Global monthly water scarcity: Blue water footprints versus blue water availability. $\quad-\quad$ PLoS ONE 7(2): e32688. https://doi.org/10.1371/journal.pone.0032688.

[13] Ibidhi, R., Ben, H. (2018): Water footprint and economic water productivity of sheep meat at farm scale in humid and semi-arid agro-ecological zones. - Small Ruminant Research 166: 101-108.

[14] IMAJ. Iran's Ministry of Agriculture Jihad: Tehran, Iran. (2018): www.maj.ir. Accessed on 1 January 2016.

[15] IMO Iran Meteorological Organization: Tehran, Iran. (2018): www. irimo. ir/fa. Accessed on 1 January. 2017.

[16] Karandish, F., Hoekstra, A. Y., Hogeboom, R. J. (2018): Groundwater saving and quality improvement by reducing water footprints of crops to benchmarks levels. - Advances in Water Resources 121: 480-491.

[17] Khaki, M., Forootan, E., Kuhn, M., Awange, J., van Dijk, A. I. J. M., Schumacher, M., Sharifi, M. A. (2018): Determining water storage depletion within Iran by assimilating GRACE data into the W3RA hydrological model. - Advances in Water Resources 114: $1-18$.

[18] Liu, J. et al. (2017): A comprehensive analysis of blue water scarcity from the production, consumption, and water transfer perspectives. - Ecological Indicators 72: 870-880.

[19] Ma, D. et al. (2015): The evaluation of water footprints and sustainable water utilization in Beijing. - Sustainability 7(10): 13206-13221. 
[20] Madani, K. (2005): Iran's water crisis: inducers, challenges and counter-measures. ERSA 45th Congress of the European Regional Science Association, January 2005, pp/ $1-20$.

[21] Madani, K. (2014): Water management in Iran: what is causing the looming crisis? Journal of Environmental Studies and Sciences 4: 315-328.

[22] Mekonnen, M. M., Hoekstra, A. Y. (2016): Four billion people facing severe water scarcity. - Science Advances 2(2). DOI: 10.1126/sciadv.1500323.

[23] Pfister, S., Bayer, P. (2014): Monthly water stress: spatially and temporally explicit consumptive water footprint of global crop production. - Journal of Cleaner Production 73: 52-62.

[24] Qian, Y. et al. (2018): Water footprint characteristic of less developed water-rich regions: Case of Yunnan, China. - Water Research 141: 208-216.

[25] Raskin, P. D., Hansen, E., Margolis, R. M. (1996): Water and sustainability. - Natural Resources Forum 20: 1-15.

[26] Rijsberman, F. R. (2004): Water scarcity: fact or fiction? - Proceedings of the 4th International Crop Science Congress, 26 Sep - 1 Oct 2004, 80: 5-22.

[27] Rijsberman, F. R. (2006): Water scarcity: fact or fiction? - Agricultural Water Management 80: 5-22.

[28] Savenije, H. H. G. (2000): Water scarcity indicators; the deception of the numbers. Physics and Chemistry of the Earth, Part B: Hydrology, Oceans and Atmosphere 25: 199-204.

[29] SCI. Statistical Center of Iran, Tehran, Iran (2016): http://www.amar.org.ir. - Accessed on 1 January 2017.

[30] Siebert, S. et al. (2010): Groundwater use for irrigation - a global inventory. - Hydrol. Earth Syst. Sci. 14: 1863-1880.

[31] Smakhtin, V., Revenga, C., Döll, P. (2004): A pilot global assessment of environmental water requirements and scarcity. - Water International 29(3): 307-317.

[32] Tillotson, M. R. et al. (2014): Water Footprint Symposium: where next for water footprint and water assessment methodology? - The International Journal of Life Cycle Assessment 19(8): 1561-1565.

[33] Umar, R. (2004): Groundwater Flow Modelling and Aquifer Vulnerability Assessment Studies in Yamuna - Krishni Sub-basin, Muzaffarnagar District. - Completion Report Submitted to Indian National Committee on Ground Water Central Ground Water Board (CGWB), Ministry of Water Resources, Govt. of India.

[34] Wada, Y., Beek, L. P. H. van, Bierkens, M. F. P. (2011): Modelling global water stress of the recent past: on the relative importance of trends in water demand and climate variability. - Hydrol. Earth Syst. Sci. 15: 3785-3808.

[35] Xinchun, C. et al. (2017): Assessing water scarcity in agricultural production system based on the generalized water resources and water footprint framework. - Science of the Total Environment 609: 587-597.

[36] Zehtabian, G., Khosravi, H., Ghodsi, M. (2010a): High Demand in a Land of Water Scarcity: Iran. - In: Schneier-Madanes, G., Courel, M.-F. (eds.) Water and Sustainability in Arid Regions: Bridging the Gap Between Physical and Social Sciences. Springer, Dordrecht, pp. 75-86.

[37] Zektser, I., Everett, L. (2004): Resources of the World and Their Use. - United Nations Educational, Scientific and Cultural Organization, Paris.

[38] Zeng, Z., Liu, J., Savenije, H. H. G. (2013): A simple approach to assess water scarcity integrating water quantity and quality. - Ecological Indicators34: 441-449.

[39] Zhuo, L. et al. (2019): Monthly blue water footprint caps in a river basin to achieve sustainable water consumption: the role of reservoirs. - Science of the Total Environment 650: 891-899. 